\title{
The Bond Strength Behavior of Polymer-modified Mortars During a Wetting and Drying Process
}

\author{
Flávio Leal Maranhã ${ }^{a, b *}$, Mauricio Marques Resende ${ }^{a}$, Vanderley Moacyr John ${ }^{b}$, \\ Mercia Maria Semensato Bottura de Barros ${ }^{b}$ \\ ${ }^{a}$ Universidade São Judas Tadeu - USJT, Rua Taquari, 546, Mooca, \\ CEP 03166-000, São Paulo, SP, Brazil \\ ${ }^{b}$ Department of Construction Engineering, Polytechnic School, Universidade de São Paulo - USP, \\ Av. Prof. Almeida Prado, 83, Travessa 2, Edifício de Engenharia Civil, Cidade Universitária, \\ CEP 05508-900, São Paulo, SP, Brazil
}

Received: September 1, 2015; Revised: October 21, 2015

\begin{abstract}
Polymer-modified mortars are highly popular for setting exterior tile systems and low-porosity ceramic tiles because they possess greater flexibility and higher bond strengths than conventional mortars which increases cladding serviceability. However, the long-term performance of this application is not completely understood and many pathologies has been reported. The negative influence of water saturation on polymer modified mortar is well documented and this paper investigates the influence that progressive water intake on bond strength by applying pull out tests on several different mortars. Four of those mortars were especially prepared with well known raw materials and concentrations, and three others were ready-made commercial products designed for setting ceramic tile on building façades. The tests were performed during twenty-five day drying period in laboratory conditions after specimens saturation for ten days of immersion in water. The results revealed that: (i) the ready-made commercial and the prepared mortars have similar behavior; (ii) their bond strengths are highly influenced by small increases in moisture content; (iii) moisture content higher than $10 \%$ is enough to reduce mortar bond strength by one-half; (iv)during the drying process bond strength increases continuously until reaching values similar to the initial ones.
\end{abstract}

Keywords: tilling, adhesive mortar, moisture content, bond strength

\section{Introduction}

Ceramic tiles set on building façades are a very popular finishing because they are resistant to soiling, have a longer service life under most weather conditions ${ }^{1}$ and consequently, lower maintenance rates when compared to painted façades. Despite these improvements, their durability is still somewhat lower than expected. Shohet \& Paciuk ${ }^{2}$ reported that in Israel the service life is around 18 years. The principal failure observed in these tiling systems are cracks in the joints ${ }^{3}$ that allow water infiltration which causes efflorescence, staining and mould growth ${ }^{4}$. These infiltrations increase the moisture content of the adhesive mortar, which modifies the polymer film performance ${ }^{5}$ and consequently reduces flexibility by about $50 \%{ }^{6}$. Moreover, the ceramic tiles may also absorb some moisture, which causes them to expand and thus, increases shear stress?.

Polymer-modified mortars are commonly used to set low porosity porcelain and stoneware tiles because they are less rigid and produce higher bond strengths in comparison with conventional mortars. Not surprisingly, lower stress has been measured between the tiling system layers ${ }^{8}$ and applications in high rise buildings have become feasible ${ }^{1,3}$.

*e-mail: flavio.maranhao@usp.br
Much of the research involving those materials focuses on microstructure ${ }^{9-12}$ polymer cement matrix interaction ${ }^{5}$, evolution of mortar hydration ${ }^{13,14}$, the film formation process $s^{15,16}$ and improvements in the mechanical properties ${ }^{17}$. But, there has been little focus on service life and the influence of moisture and other degradation agents have on tiling system performances. Generally, the authors have pointed out that the higher the polymer/cement ratio, the higher the flexibility, the flexural and bond strength to low porosity substrates are.

The intensity with which water provoked polymer-modified mortar alterations occur depends on the type of polymer used in the formulation. According to Jenni et al. ${ }^{9}$, cellulose, PVA and cellulose Ether can be classified as water soluble, while VAC-VeoVa (vinyl acetate vinyl versate copolymer) and VAE (Vinyl acetate/ethylene copolymer) as water-resistant. Although Utida et al. ${ }^{18}$ did not identify any major differences for the same polymers when evaluating tensile bond strength, Maranhão et al. ${ }^{19}$ concluded from transversal deformation results that EVA produces a better performance than VAC-VeoVa when submitted to wet-dry cycles

Despite of a consensus affirming the damaging effects of water on polymer modified mortars, it is not clear whether limited water intakes (e.g. due to tiling grout failures) cause mortar degradation or if complete saturation is necessary as 
is specified in European Standard EN 1348 ${ }^{[20]}$. This regard is in view of the contradicting results which have been published. Supported by natural aging essays covering periods of up to 10 years, authors such as Perényi ${ }^{21}$, and Shulze \& Killermann ${ }^{22}$ advocate that there are increases in tensile flexure, the compressive and bond strengths of these mortars which are related to the continuous hydration of the cement matrix; whereas, Sá \& Freitas ${ }^{23}$ and Yiu et al. ${ }^{24}$ measured reductions greater than $50 \%$ in the bond and shear strengths of ceramic tiles subjected to artificial aging cycles in laboratory scale; and Guan \& Alum ${ }^{25}$ analyzing detachment cases in Singapore, measured a bond strength reduction of $40 \%$ when comparing external and internal results.

The aim of this work is to investigate the influence of progressive moisture content on the bond strength behavior of polymer modified mortars used to set low porosity ceramic tiles submitted to wetting and drying storage conditions.

\section{Material and Methods}

\subsection{Specimens preparation}

Seven different dry-set mortars were evaluated, five during a drying process and two during wetting. Four of the seven mortars were prepared using known raw materials and polymer concentrations, and the other three used common commercial products found on the Brazilian market.

The mixture procedures were based on Brazilian Standard NBR $14082^{[26]}$ specifying that the powder must be added to the water gradually and mixed for two minutes using a laboratory planetary mixer followed by a maturation time of fifteen minutes.
The mortars were applied directly on a standard concrete substrate using a $6 \mathrm{~mm} \times 6 \mathrm{~mm}$ trowel. Five minutes after this application the tiles were positioned and pressed with a $2.0 \mathrm{~kg}$ dead load for $30 \mathrm{~s}$. Ten specimens were used for each substrate. Those procedures are specified by EN $1348^{[20]}$. Twenty -four hours after setting all substrates were placed in a chamber with high relative humidity (higher than 99\%) for 48 hours to guarantee cement hydration. They were then exposed to indoor conditions with temperatures varying from $25+5{ }^{\circ} \mathrm{C}$ and humidity $50-80 \%$ for 26 days. The substrates were then soaked in water for ten days and simultaneously removed and stored in piles in a laboratory environment for 25 days (Figure 1). Bond strength tests were conducted during this drying period (38 to 63 days), and after each pull-out test, each specimen was individually measured for moisture content. One substrate for each mortar was not immersed in water and used as a reference for dry results.

The wetting tests were similar for the first 28 days (Figure 1). After this, the specimens were immersed in water and pull out tests were conducted during a 10 day period.

\subsection{Materials}

The prepared mortars used the same composite cement (around 30\% of bfs) and limestone aggregate. The polymer was a Vinyl acetate/ethylene copolymer (VAE) produced by Wacker, and the cellulose polymer was the methylcellulose derivate produced by Aqualon. All the content shown in Table 1 is related to the total weight of dry materials. Table 2 also presents some properties of those polymers as stated by the manufactures. The ceramic tiles used in the experiments were commercial $50 \mathrm{~mm} \times 50 \mathrm{~mm}$ porcelain stoneware with

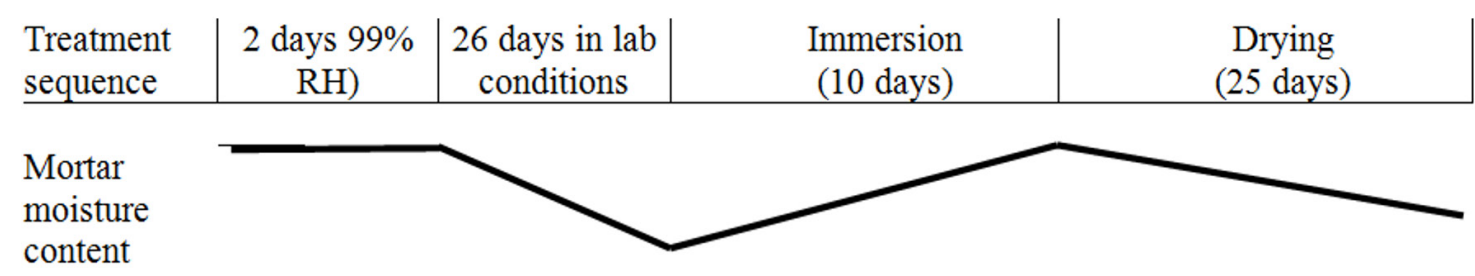

\begin{tabular}{l|lr|r|}
\hline Pull-out tests age: & \multicolumn{2}{c|}{ Wetting Tests } & \multicolumn{2}{c|}{ Drying Test } \\
\hline 28 days & \multicolumn{2}{c|}{38 days } & 63 days
\end{tabular}

Figure 1. Experimental sequence for the drying test, schematically explaining the moisture content variation over time and the ages of the pull-out tests.

Table 1. Mortar formulations. All values refer to total dry weight.

\begin{tabular}{cccccc}
\hline Mortar & Cement content & $\begin{array}{c}\text { Cellulose } \\
\text { content }\end{array}$ & $\begin{array}{c}\text { VAE } \\
\text { content }\end{array}$ & $\begin{array}{c}\text { Water/dry } \\
\text { materials ratio } \\
\mathbf{( w / w )}\end{array}$ & Testing Method \\
\hline $\mathrm{A}$ & $40 \%$ & $1.0 \%$ & $20 \%$ & 0.4 & During drying \\
$\mathrm{B}$ & $20 \%$ & $0.5 \%$ & $20 \%$ & 0.22 & During drying \\
$\mathrm{C}$ & $20 \%$ & $0.5 \%$ & $5 \%$ & 0.25 & During drying \\
$\mathrm{D}$ & $\mathrm{Nd}$ & $\mathrm{Nd}$ & $\mathrm{Nd}$ & 0.23 & During drying \\
$\mathrm{E}$ & $\mathrm{Nd}$ & $\mathrm{Nd}$ & $\mathrm{Nd}$ & 0.23 & During drying \\
$\mathrm{F}$ & $30 \%$ & $0.5 \%$ & $10 \%$ & 0.20 & During wetting \\
$\mathrm{G}$ & $\mathrm{Nd}$ & $\mathrm{Nd}$ & $\mathrm{Nd}$ & 0.20 & During wetting \\
\hline
\end{tabular}


$0.1 \%$ water absorption, according to Brazilian Standard NBR $13818^{[27]}$.

The commercial mortars (D, E and G) are classified by the manufactures as type ACIII and based on local standards which have requirements similar to $\mathrm{C} 2 \mathrm{~S}$ in the European standard.

\subsection{Test methods}

Bond strength evaluations are based on EN $1348^{[20]}$, using the direct pull-out test with a load cell unit of $5.0 \mathrm{kN}$. At least sixty pull-out tests were performed for each mortar totaling 640 results.

To measure the humidity a sample of still wet mortar was scraped from the layer on the back of each ceramic tile and weighed, giving the moist mass value (Figure 2). This damp, grated mortar was then placed in a ventilated oven at $100^{\circ} \mathrm{C}$ until its mass value became constant. The mortar was weighed a second time, revealing its dry-mass value. The humidity is expressed as a percentage of dry mass and the well know $\mathrm{CSH}$ dehydration at temperatures higher than $70^{\circ} \mathrm{C}$ was not considered, since it does not have important influences on adhesion low porosity surface. Precision scales (1 mg accuracy) were used and $1.5 \mathrm{~g}$ was the minimum weight per sample, as the investigation focuses on the rupture surface.

Table 2. The properties of the polymers used in the experiments, as published by the manufacturers.

\begin{tabular}{lccc}
\hline & & VAE $^{1}$ & Cellulose $^{2}$ \\
\hline $\begin{array}{l}\text { Bulk Density } \\
\begin{array}{l}\text { Particle size } \\
\text { grading }\end{array}\end{array}$ & $(\mu \mathrm{g} / \mathrm{m})$ & $\begin{array}{c}490-590 \\
\text { Max. 4\% }\end{array}$ & $\begin{array}{c}\text { DV9-500-295 } \\
\text { over 400 } \mu \mathrm{m}\end{array}$ \\
$\begin{array}{l}\text { Brookfield R.V.T } \\
\text { viscosity }\end{array}$ & $\mathrm{mPa} . \mathrm{s}$ & $\mathrm{nd}$ & $65,000-85,000$ \\
$\begin{array}{l}\text { Particle diameter } \\
\text { at dispersion }\end{array}$ & $(\mu \mathrm{m})$ & $0.5-8$ & $\mathrm{nd}$ \\
$\begin{array}{l}\text { Minimum } \\
\text { film forming } \\
\text { temperature }\end{array}$ & $\left({ }^{\circ} \mathrm{C}\right)$ & $4^{\circ}$ & $\mathrm{nd}$ \\
\hline
\end{tabular}

\section{Results and Discussion}

Figure 3 shows the bond strengths at three ages: dry condition (28 days), after 10 days immersion (38 days) and after 25 days of additional drying (63 days).

The results clearly show that immersion caused an important reduction in bond strength for all the mortars and that the additional 25-day drying period allowed some recovery. Before immersion all mortars showed average bond strengths higher than 1.0 MPa with no notable influence from cement content. After immersion the values ranged from $0.215 \mathrm{MPa}$ to $0.53 \mathrm{MPa}$. These values are lower than those specified by EN $12004^{[28]}$ despite a likely increase in the mechanical strength of the cement matrix due to increased hydration of blast furnace slag and clinker phases of the cement. The lower values represent from $65 \%$ to $88 \%$ of the initial (dry) adhesion, which is coherent with published literature ${ }^{10,29}$. This reduction is usually attributed to the hydrolysis and swelling of the polymer film ${ }^{30}$ which is important when using low porosity tiles such as those employed in the experiments. The VAE polymer content did not exert important influences (B vs C) bond strength results under saturated condition, as previously confirmed by Felixberger ${ }^{31}$.

After a twenty-five-day drying period (63 days old), the mortars showed significant recovery in bond strength, reaching values higher than $0.80 \mathrm{MPa}$. However, this value is $2 \%$ (mortar D) to $30 \%$ (mortar B) lower than the original dry results. This behavior reveals that the effects of saturation can be partially reversible, in accordance to Silva $\&$ Monteiro $^{30}$. A less than complete recovery was probably linked to the low porosity tiles used in the experiments seeing that Jenni et al. ${ }^{9}$ has already shown that recovery can be as high as $90 \%$ for porous substrate after four wet-dry cycles.

During the experiments the moisture content of the mortars varied from 2.3-3.0\% after 28 days of curing (before immersion), to $13-31 \%$ after 10 days of immersion, and returned to values up to $4 \%$ after 25 days of drying (Figure 4 ). All mortars produced similar behavior in reducing moisture content, including faster kinetics, during the first five days, followed by a period with lower rates. The large same day dispersion, was most likely caused by the manner in which the

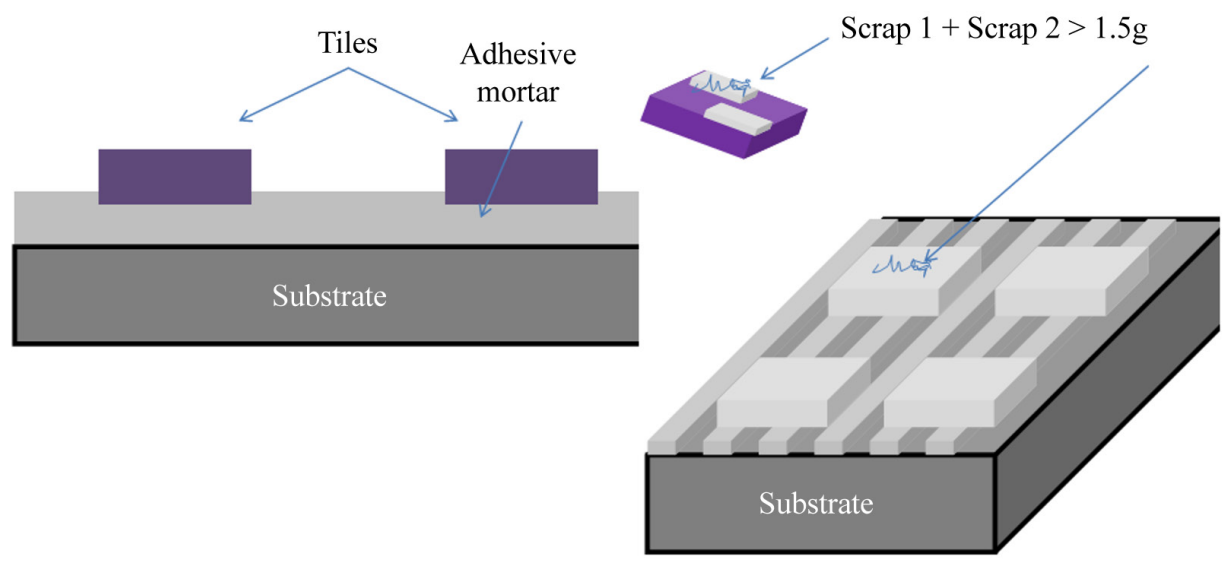

Figure 2. Method used to collect the damp mortar samples after the bond strength test. 


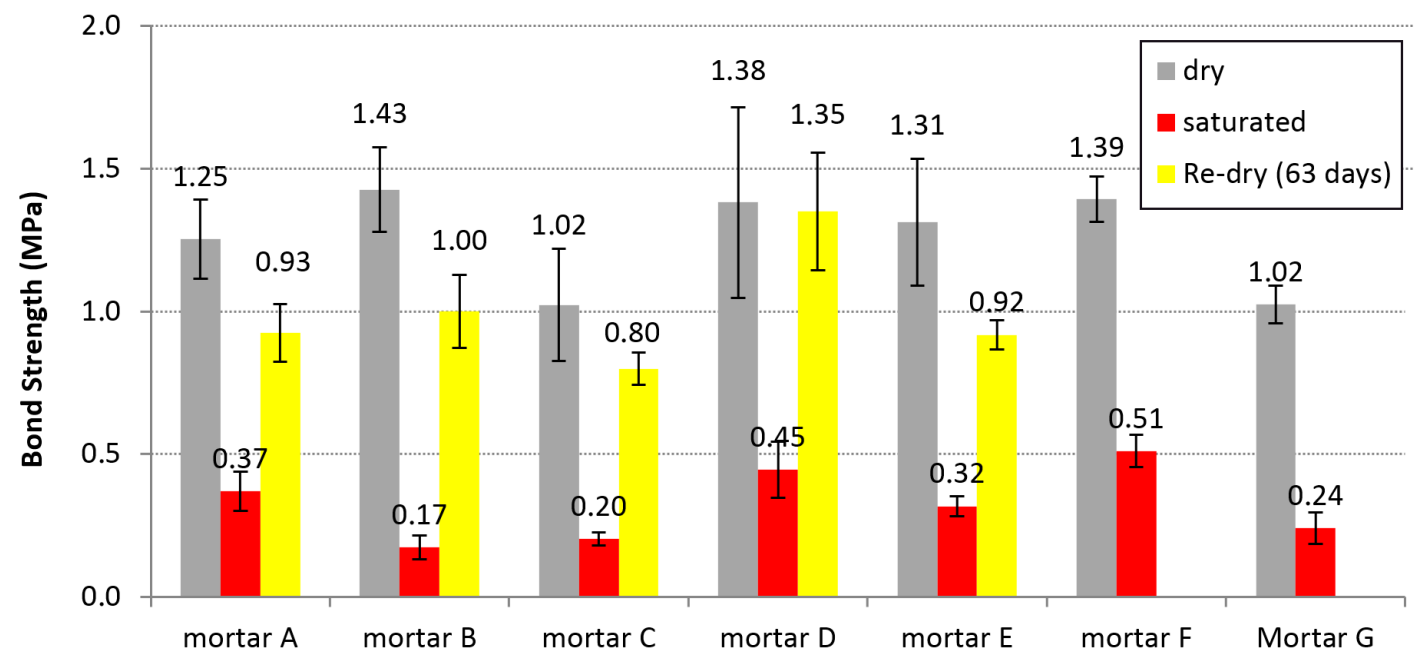

Figure 3. Average bonding strength results for different mortars after dry-curing (dry, 28 days), 10 days of immersion (wet, 38 days) and after 25 days of drying (Re-dry, 63 days).

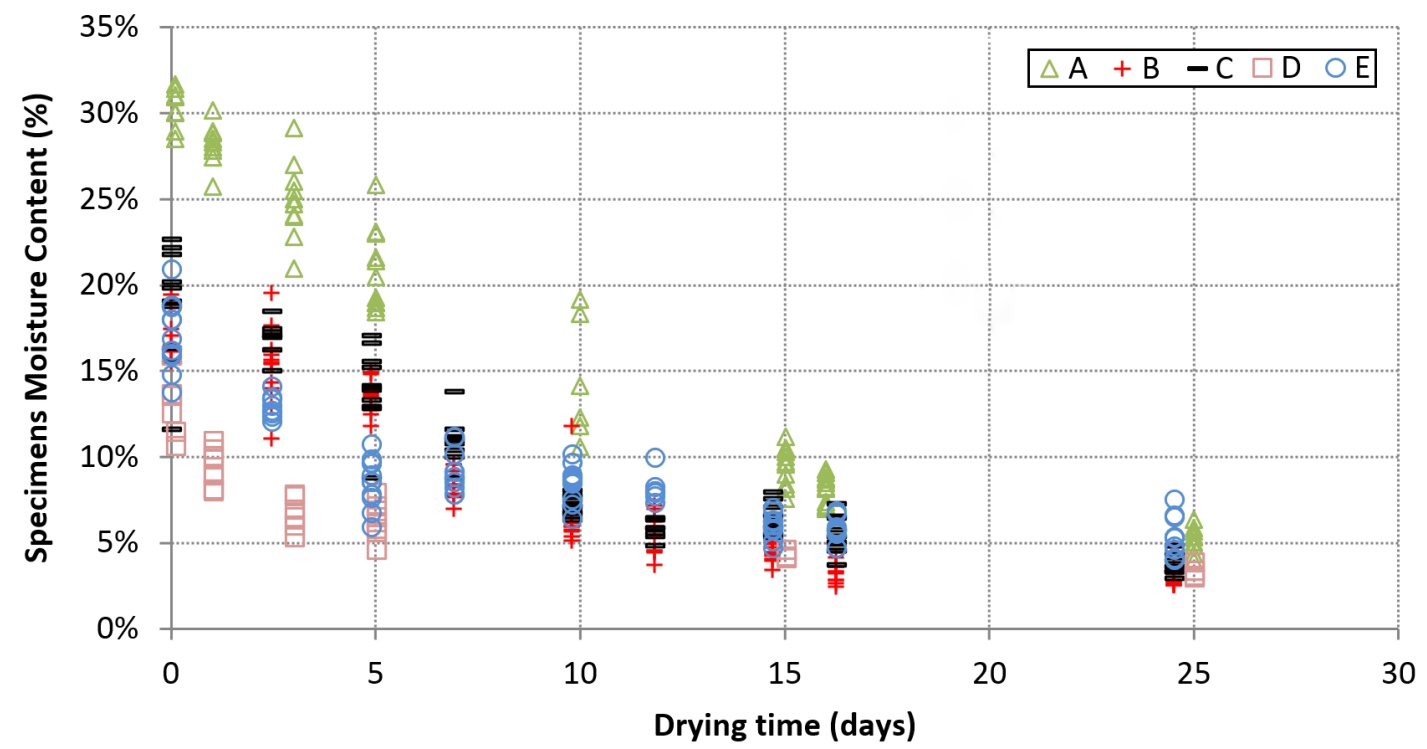

Figure 4. Moisture variation versus drying time after the 10 day immersion period.

substrates were piled for storage. The extended time it takes for the mortars to dry is due to the ceramic tile's protective covering and MHEC content which reduces permeability ${ }^{32}$.

During wetting (Figure 5), the water intake was slower than normally measured on porous materials as mortars and fit an almost linear function. This behavior is caused by the polymeric film phase, which has a hydrophobic characteristic and reduces capillarity ${ }^{9,22}$. In this case less than 12 hours of immersion were necessary to reach $5 \%$ of moisture content and seven days to reach $90 \%$ saturation, considered as ten days of immersion.

After 10 days of immersion the highest moisture content measured was in mortar A. As 10 days is a rather long period of immersion this value is probably related to an abundance of pores which resulted from the increased volume of entrapped air caused by the high content of MHEC $^{29,32}$. All other mortars showed similar average moisture contents, ranging from $13 \%$ to $18 \%$. Mortar D, with the lowest average moisture content after 10 days of immersion, had the highest bond strength after drying, recovering almost all of its original bonding strength.

Figures 6 and 7 plot the bond strength versus moisture content. Figure $6 \mathrm{a}$, b show drying results and Figure 7, the wetting. In all cases the higher the moisture content was, the weaker the bond strength was too. The typical profile measured can be divided into three parts: one, small increases in humidity content from $\sim 2$ (equilibrium) to $\sim 5 \%$ lead to significant reductions in bonding strength, two, increases from $6 \%$ to $10 \%$ less intense reductions, and the third group, with humidity increases higher than $10 \%$, that apparently represents a point at which no important reductions were measured. Despite different formulations and different 


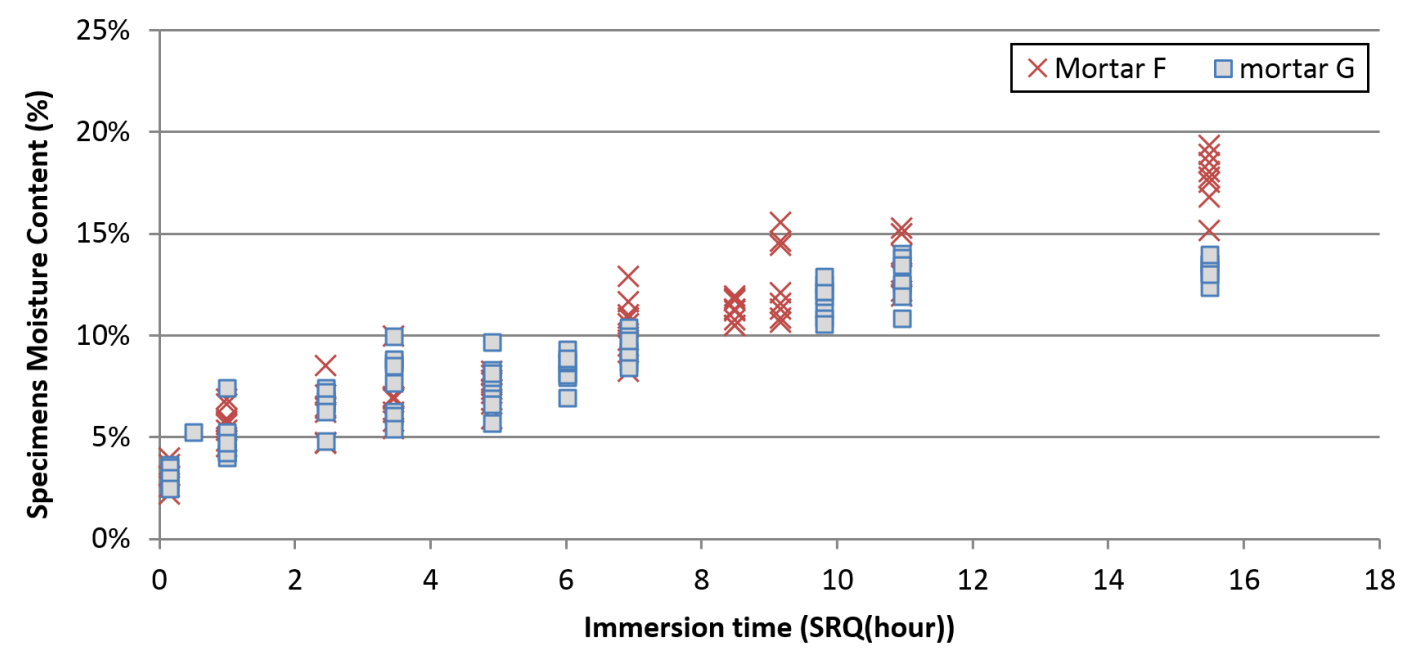

Figure 5. Moisture variation versus immersion time along 10 days.

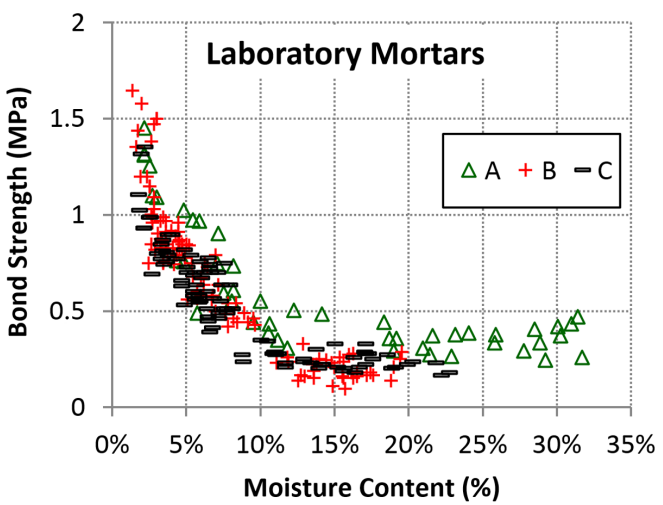

(a)

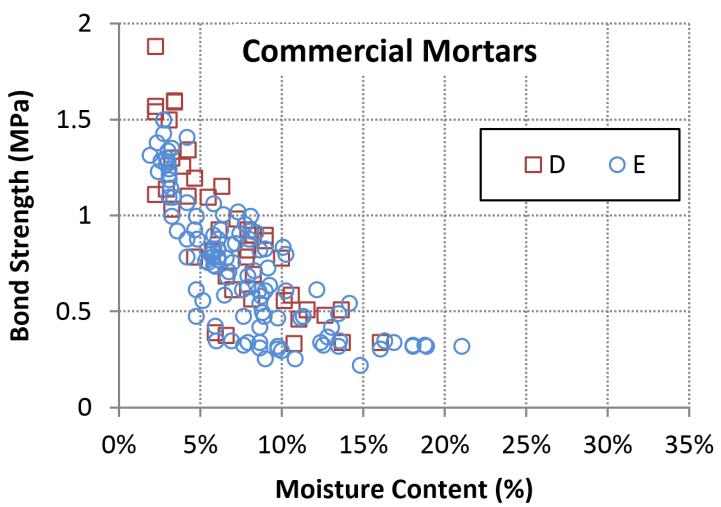

(b)

Figure 6. Influence of the moisture content on the bond strength during drying process for laboratory prepared mortars (a); and commercial mortars (b).

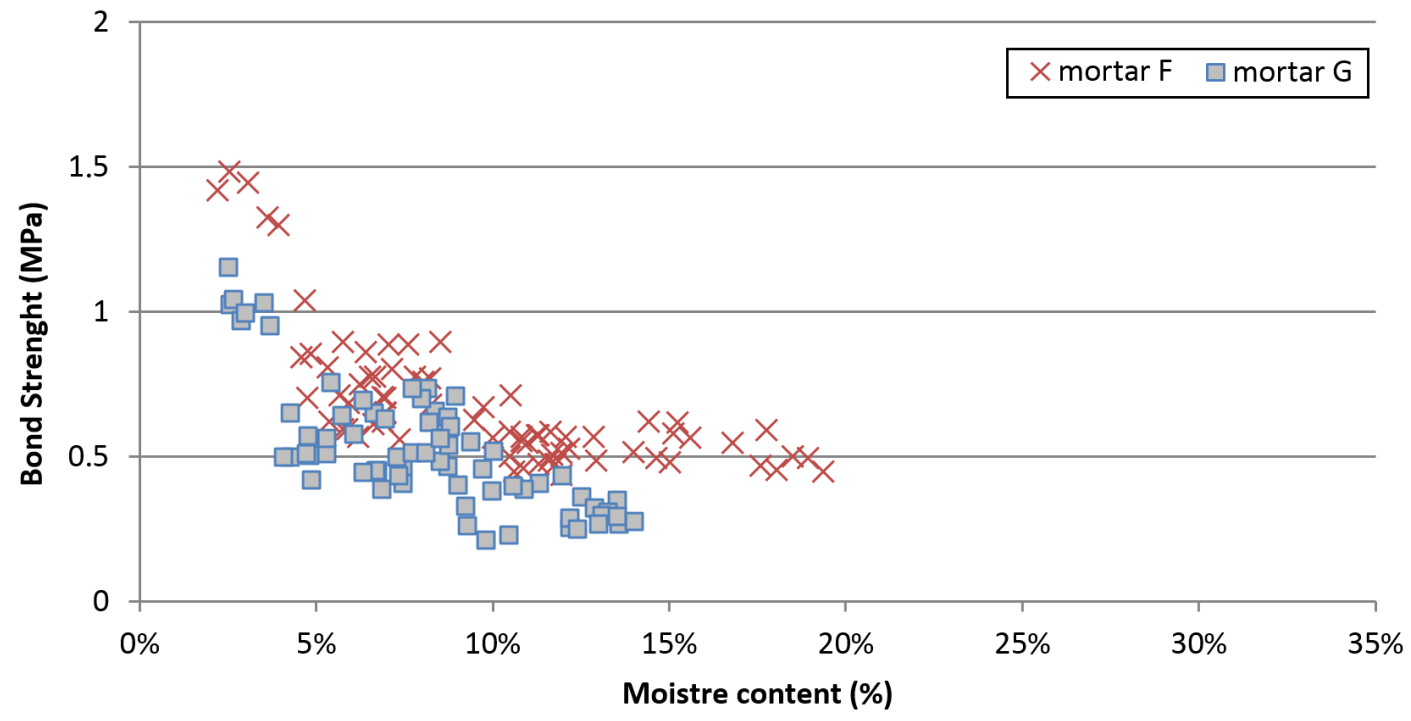

Figure 7. Variation of the moisture content on the bond strength during wetting. 
wetting and drying conditions all the evaluated mortars produced similar profiles, but further results are necessary to confirm this behavior.

Maranhão et al. ${ }^{19}$ identified similar behavior when evaluating transversal deformations of polymer-modified mortars with compositions comparable to those used in this study. In both cases, the polymer film phase, which determines mortar flexibility and adherence to low-porosity tiles such as the porcelain stoneware used in this work, significantly influences the mortar's performance.

The experiments revealed that less than 2 hours of immersion were sufficient to reduce initial bond strength by $50 \%$ and after 48 hours of immersion no important differences were measured. No result higher than 0.60 MPa was achieved with moisture content higher than $10 \%$, and except for mortar D, no other mortar having moisture content higher than $6 \%$ produced bond strength higher than $1.0 \mathrm{MPa}$
Figure 8 shows a clear correlation of bond strengths normalized at the highest value for each mortar and the moisture. Data shows that even the slightest increase in moisture content can provoke a significant reduction in the mortar's bond strength. Tests revealed that a moisture content of $5 \%$ can result in a reduction of around $50 \%$ in bond strength and $10 \%$ moisture can cause a reduction near $75 \%$. A correlation index higher than 0.80 was obtained individually for each mortar with a logarithmic function.

This behavior in a real façade could seriously affect the performance of external tile systems which commonly present cracks in the grout mortar that allow rain water infiltration leading to reductions in bond strength. Therefore, in regions of frequent rainfall, the mortar might never become completely dry. Consequently, reductions in mortar bond strength should be expected.

Based on all results, Figure 9 presents a generic profile of the influence of moisture content on bond strength behavior.

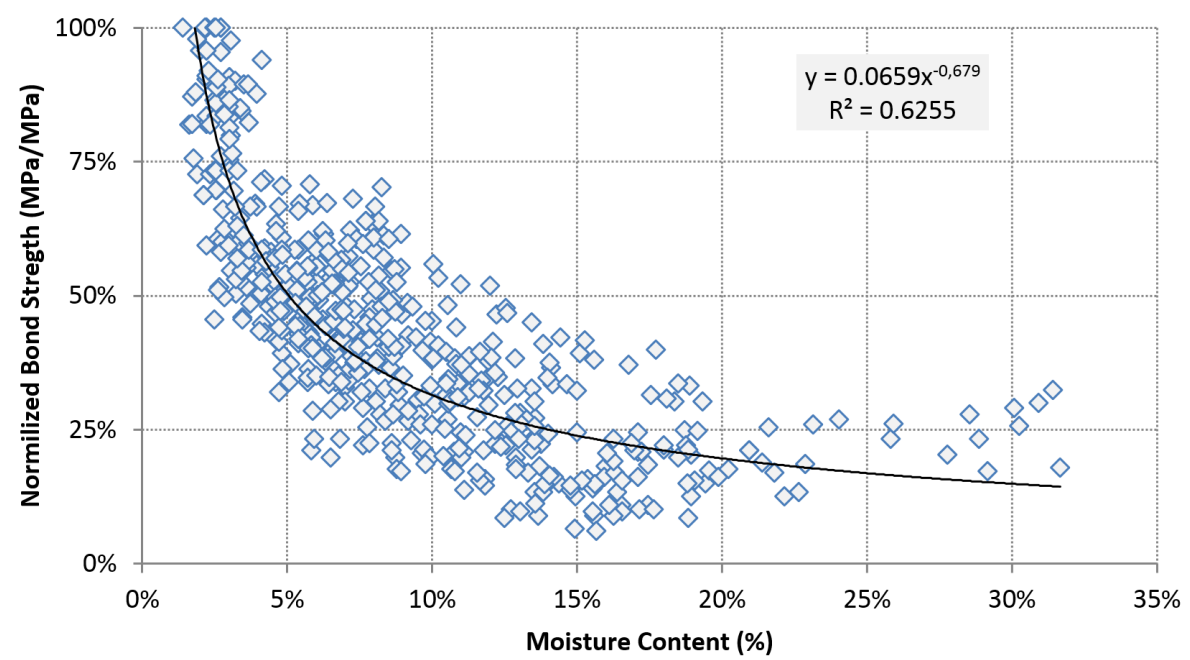

Figure 8. Normalized bond strength results versus moisture content. Bond strength equal to 1 corresponds to the minimum measured moisture content.

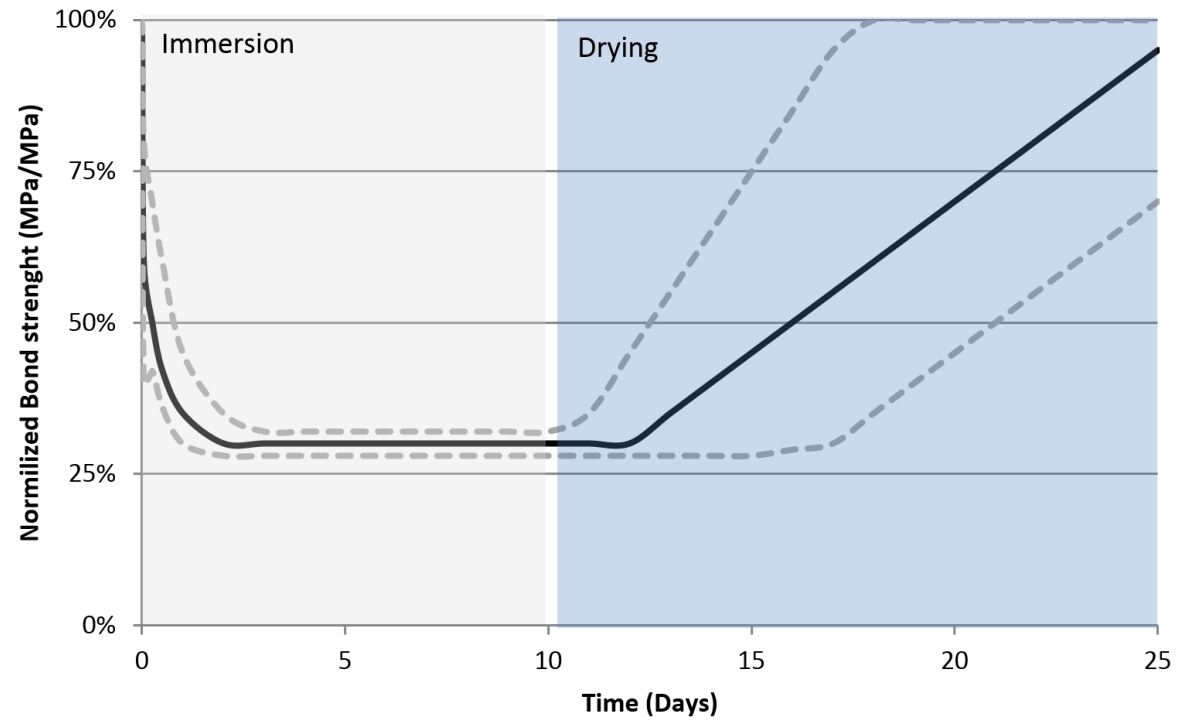

Figure 9. Proposed generic behavior based on the experimental program. 
During wetting, reductions are faster and it only takes a few hours to degenerate mortar properties. It takes several days for the saturated mortar to become dry and recover. The dispersion is in function of the mortar properties.

\section{Conclusion}

The experimental data shows that small increases in moisture content can produce significant bond strength reductions in mortars used to set low porosity tiles. As little as $5 \%$ water absorption can cause a $50 \%$ reduction in bond strength; moisture absorptions of $10 \%$ or more result in

\section{References}

1. Ho D, Lo SM, Yiu CY and Yau LM. A survey of materials used in external wall finishes in Hong Kong. Hong Kong Surveyor. 2004; 15(2):7-11.

2. Shohet I and Paciuk M. Service life prediction of exterior cladding components under standard conditions. Construction Management and Economics. 2004; 22(10):1081-1090. http:// dx.doi.org/10.1080/0144619042000213274

3. Maranhão F, Silva AC and Medeiros JS. Building façade with porcelain stoneware tiles in Recife - Brazil. In: Proceedings of the 9th World Congress on Ceramic Tile Quality; 2006; Castellón, Spain. Castellón: QUALICER; 2006. p. 95-105.

4. Silvestre J and Brito J. Statistical analysis of defects of tiles' joints. Materiales de Construcción. 2007; 57(285):85-92.

5. Silva D and Monteiro P. ESEM analysis of polymeric film in EVA-modified cement paste. Cement and Concrete Research. 2005; 35(10):2047-2050. http://dx.doi.org/10.1016/j. cemconres.2004.10.037.

6. Fritze P. Deformability and water resistance of $\mathrm{C} 1$ and $\mathrm{C} 2$ according to EN 12004. In: Proceedings of the 5th World Congress on Ceramic Tile Quality; 1998; Castellon, Spain. Castellón: QUALICER; 1998. p. 3-16.

7. Toakley AR and Waters EH. Stresses in ceramic tiling due to expansion and shrinkage effects. Building Science. 1973; 8(3):269-281. http://dx.doi.org/10.1016/0007-3628(73)90009-1.

8. Roman LMF, Roman H, Silva DA and Alarcon OE. The influence of grout thickness on the adherence of ceramic tiling systems. In: Proceedings of the 6th World Congress on Cerami Tile Quality; 2000; Castellon, Spain. Castellón: QUALICER; 2000. p. 31-38.

9. Jenni A, Zurbriggen R, Holzer L and Herwegh M. Changes in microstructures and physical properties of polymer-modified mortars during wet storage. Cement and Concrete Research. 2006; 33(36):79-90. http://dx.doi.org/10.1016/j.cemconres.2005.06.001.

10. Ohama Y. Polymer-based admixture. Cement and Concrete Composites. 1998; 20(2-3):189-212. http://dx.doi.org/10.1016/ S0958-9465(97)00065-6.

11. Su Z. Microstructure of polymer cement concrete. [Thesis]. Netherlands: Delf University of Technology; 1995. 174 p.

12. Gomes CEM, Ferreira OP and Fernanes MR. Influence of vinyl-versatic vivilelter copolymer on the microstructural of cement pastes. Materials Research. 2005; 8(1):51-56.

13. Silva DA, John VM, Ribeiro JLD and Roman HR. Pore size distribution of hydrated cement pastes modified with polymers. Cement and Concrete Research. 2001; 31(8):1177-1184. http:// dx.doi.org/10.1016/S0008-8846(01)00549-X. bond strength reductions of $75 \%$ or higher. As frequently occurring localized failures in tiling system grout allow water infiltration, an increase in moisture content during service life and consequent adhesive performance decrease should be expected.

For the evaluated mortars the increase of polymer/cement did not influence the results whereas, mortar B (with a $\mathrm{P} / \mathrm{C}$ ratio of 1.0 ) and mortar $\mathrm{C}$ (with a $\mathrm{P} / \mathrm{C}$ ratio of 0.25 ) produced similar results. Even so, a reduction in the water/cement ratio by addition of a dispersion agent in mortar formulations could minimize the degenerative effect of moisture on tilling performance.

14. Silva D and Monteiro P. Hydration evolution of $\mathrm{C}_{3}$ S-EVA composites analyzed by soft X-ray microscopy. Cement and Concrete Research. 2005; 35(2):351-357. http://dx.doi. org/10.1016/j.cemconres.2004.05.049.

15. Afridi MUK, Ohama Y, Demura K and Iqbal MZ. Development of polymer films by the coalescence of polymer particles in powdered and aqueous polymer-modified mortars. Cement and Concrete Research. 2003; 33(11):1715-1721. http://dx.doi. org/10.1016/S0008-8846(02)01094-3.

16. Póvoas YV. Evolution of the film formation on the ceramic tile adhesive. [Thesis]. São Paulo: Universidade de São Paulo; 2005. 140 p. (in Portuguese).

17. Bureau L, Alliche A, Pilvin P and Pascal S. Mechanical characterization of a styrene-butadiene modified mortar. Materials Science and Engineering. 2001; 308(1-2):233-240. http://dx.doi.org/10.1016/S0921-5093(00)01980-8.

18. Utida M, Lourenço $\mathrm{W}$ and Peter $\mathrm{U}$. The Influence of different polymer types and concentration in dry-set mortar. In: Proceedings of the 6th International Symposium on Mortars Technology; 2005; Florianopolis, Brazil. Florianopolis: UFSC; 2005. p. 406-413.

19. Maranhão F, Loh K and John VM. The influence of moisture content on the transversal deformation of polymer modified mortar. Construction and Building Materials. In press.

20. European Standards - EN. EN 1348: determination of tensile adhesive strength for cementitious adhesives. Brussels: CENELEC; 2000.

21. Perényi C. Polymer modified mortars. Materiaux et construtions. 1968; 1(1):13-21. http://dx.doi.org/10.1007/BF02478995.

22. Schulze $J$ and Killermann O. Long-term performance of redispersible powder in Mortar. Cement and Concrete Research. 2001; 3331(3):357-362. http://dx.doi.org/10.1016/S00088846(00)00498-1.

23. Sá A and Freitas V. Cementitious adhesives performance during service life. In: Proceedings of the 10th DBMC International Conference on Durability of Building Materials and Components; 2005; Lyon, France. 2005. Available from: <http://www.irbnet. de/daten/iconda/CIB_DC24729.pdf >.Access in: 01 Sept. 2015.

24. Yiu CY, Ho DC and LO SM. Weathering effects on external wall tiling system. Construction \& Building Materials. 2007; 21(3):594-600. http://dx.doi.org/10.1016/j.conbuildmat.2005.11.002.

25. Guan W and Alum J. External wall tiling in tropical city of Singapore. Singapore: Centre for Advanced Construction Studies; 1997. $101 \mathrm{p}$.

26. Associação Brasileira de Normas Técnicas - ABNT. NBR 14082: argamassa colante industrializada para assentamento 
de placas cerâmicas: execução do substrato-padrão e aplicação de argamassa para ensaios. Rio de Janeiro: ABNT; 2004.

27. Associação Brasileira de Normas Técnicas-ABNT. NBR 13818 - anexo C: placas cerâmicas para revestimento, especificação e métodos de ensaios. Rio de Janeiro: ABNT; 1997. p. 14-16.

28. European Standards - EN. EN 12004: adhesives for tiles: definitions and specifications. Brussels: CENELEC; 2002.

29. Oliveria J, Silva D and Gomes LA. Effect of wetting and drying on the behavior of polymer-modified cement materials. IBRACON Materials Journal. 2005; 1(1):59-74.
30. Silva D and Monteiro P. ESEM analysis of polymeric film in EVA-modified cement paste. Cement and Concrete Research. 2005; 35(10):2047-2050. http://dx.doi.org/10.1016/j. cemconres.2004.10.037.

31. Felixberger JF. Polymer-modified thin-bed adhesives. Version. 12.08.2008. Castellón: IPC; 2009. 109 p. Available from: $<\mathrm{http}: /$ www.ipc.org.es>. Access in: 01 June 2010.

32. Pourchez J, Ruot B, Debayle J, Pourchez E and Grosseau P. Some aspects of cellulose ethers influence on water transport and porous structure of cement-based materials. Cement and Concrete Research. 2010; 40(2):242-252. http://dx.doi. org/10.1016/j.cemconres.2009.09.028. 